 \\ jDss | Journal of Development and Social Sciences WWW.Jdss.org.pk \\ RESEARCH PAPER
}

\section{Despair in The Alchemist by Ben Jonson}

\author{
${ }^{1}$ Dr. Fatima Syeda* ${ }^{2}$ Dr. Faiza Zaheer $\quad{ }^{3}$ Numrah Mehmood
}

1. Assistant Professor, Department of English, Forman Christian College (A Chartered University), Lahore, Punjab, Pakistan

2. Assistant Professor, Department of English, Forman Christian College (A Chartered University), Lahore, Punjab, Pakistan

3. Lecturer, Department of English, Kinnaird College for Women, Lahore, Punjab, Pakistan

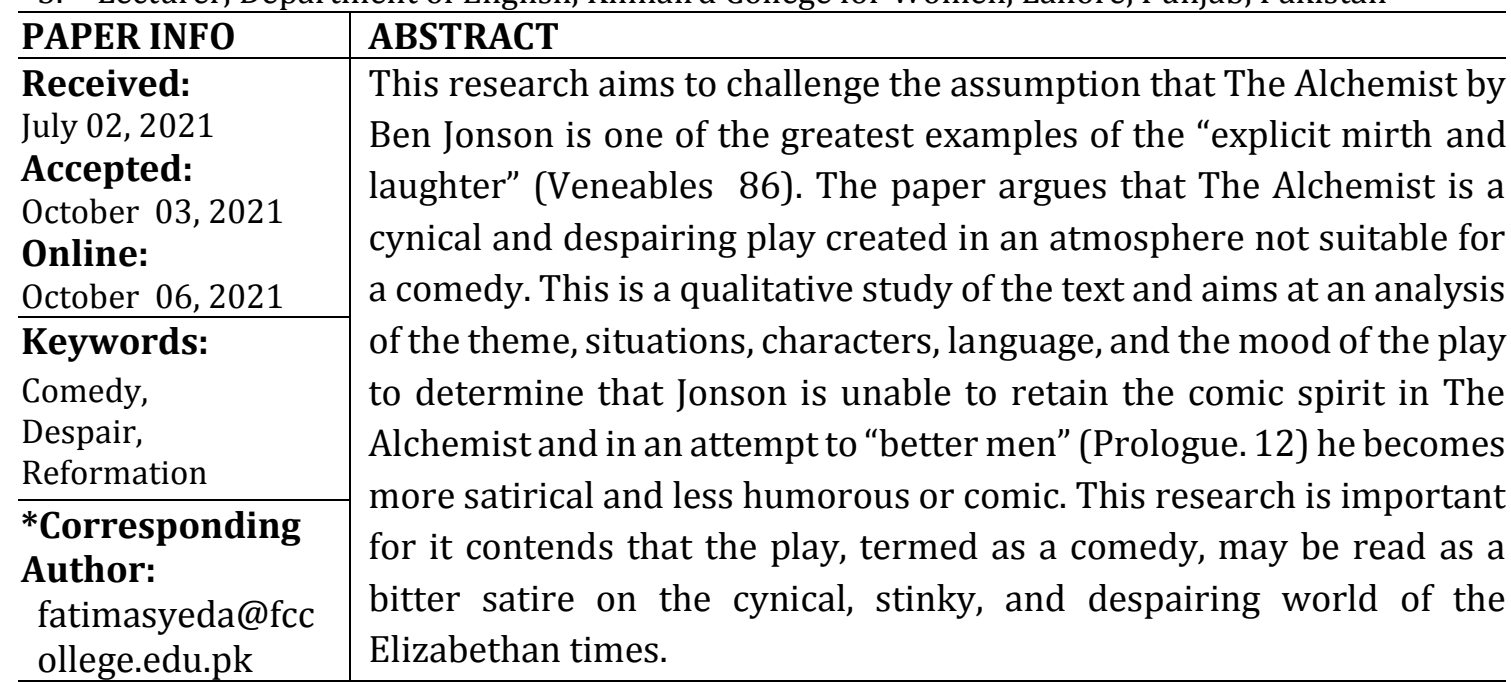

\section{Introduction}

The world created in The Alchemist is depraved of virtue, truth or beauty, all of which seem to be unimportant or even non-existent in this world. The vacuum created by the absence of these positive attributes is further filled in with negative values such as viciousness, untruth and ugliness introduced in the characters and themes as well as in the general mood of the play. This non-existence of anything positive and the dominance of all the negative, troubles the mood of comedy. It does not let one rejoice the comic elements in it. Rather, it leaves an embittered sense of desperation in the mind of the reader or the audience.

A comedy usually deals with the humorous and the familiar events. And since its purpose is to amuse, its tone is usually less serious than that of a tragedy. There is a mood of celebration, lightness, happiness, festivity or at least satisfaction at the end of a comedy. But all these attributes of comedy are lessened or faded in The Alchemist. The frame of a comedy is there but within it there is a presentation of negative values to such an extent that it verges on desperation, thus distorting the finer outline of the comedy. Irony, satire and wit, though elements of comedy, are used in such a way so as to invert Jonson's intention to "better men" (Prologue. 12). Though he initially claims to have written the play not to "grieve men" (Prologue. 12), he finally ends up doing so. For instance, the "natural 
follies" (Prologue. 23) of the characters develop into vice which does not only lead to absurdity, as is usually the case in comedies. Here, the vice leads to viciousness that includes greed, lust, untruth, and ugliness, the only ingredients constituting the world depicted in the play. For instance, at the end of the play the characters come to believe in the futility of practicing honesty. Surly exclaims, "Must I needs cheat myself, \ with that same foolish vice of honesty!" (V.iii.83-84). Such are the cynical remarks that mar the spirit of the comedy and create a despairing atmosphere, which is visible throughout the play.

The general mood of the play is plaguy i.e. sick. The play starts with the very reference to plague and sickness. The very first line of "The Argument" is "The sickness hot, a master quit, for fear," (The Argument 1). It sets the mood of the play so much so that this sickness can be seen as prevailing upon the whole of the play, literally as well as metaphorically. There are so many references to disease and sickness e.g. Face describes Subtle as "Piteously costive" (I.i.28) and "Stuck full of black melancholic worms" (I.i.30). There are references to "the pox and plaguy houses. \Moorfields for lepers" (I.i.503-504) and to the diseased people as having the gout, palsy, dropsy, decayed face or the venereal diseases. In the very first scene, it is made clear that the basis of the business contract of the three partners i.e. Face, Subtle, Doll is plague. As their means to thrive is plague, so, there is something unnatural about them from the very beginning. Their business can only be secure, "while there dies one a week $\backslash 0$ ' the plague," (I.i.182-183). They appear to be worms that live on sick and diseased places and so are as poisonous and as harmful as the disease itself. William Blissett says, "Subtle flourishes only in the bad air of the plague: He is a pest in time of pestilence: rid of one, rid of the other." (Blisset 86). Talking about Subtle, Ananaias says: He bears / The visible mark of the beast in his forehead. (III.i.7-10).

E. B. Partridge explains the allusions referred to by Ananias of the mark on forehead and etc. and says, "Ananias' biblical allusion makes them [Face and Subtle] appear as plagues." (Partridge 118). This explanation of human beings in terms of diseases reflects Jonson's aim to satirize the society in general. But the way he does this definitely affects the mood of comedy. The sickness is shown as afflicting not only body but also the souls of the characters in the play. It so affects them that they are not capable of practicing goodness any more. The delineation of such characters deprives Jonson of creating a pure comic atmosphere. Henry Wells comments on this as "Although Jonson seems most at home when flushing the gutters of Jacobean London with his torrential satire, he occasionally approaches the spirit of high comedy." (Wells 195)

Anne Barton views the play as one of the funniest play of Ben Jonson in which Jonson achieves the highest comic effect. But this is what cannot be realized, actually in the play. The first scene which helps to develop the tone of play, presents a world in which the human beings are calling each other by the names of animals. As the play develops, one can realize that Jonson has not only described men as animals but also presented them as such. Doll is called a bitch during the quarrel and Face and Subtle call each other "mastiffs, $\backslash$ Mongrels, Notorious whelps" (I.i. 10.11.21). In this quarrel, such a disgusting picture of humanity is presented that it can in no way be called funny or comic as described by Barton. Doll calls Face and Subtle as "abominable pair of stinkards," (I.i.117), "baboons" (I.i.163) and "perpetual curs" (I.i.136). And they prove themselves to be 'perpetual curs' who are all the time barking at each other. 
In short, Jonson has created a world of snarling animals that live on other beings or on each other. The presentation of such a world makes one doubt that in this play, "Jonson shows man as potentially no more than a beast or suggests that he must always remain no more than a collection of 'haire 0 ' the head, burnt clouts, chalke, merds, and clay." (Kernan 172). No one can rejoice in the face of such a desperate and hopeless presentation of humanity. Rather the cynicism can be felt throughout because the world is presented as "a cage of unclean birds" (V.i.140). Ignoring the possibility of a potential for goodness, Jonson has not given even a single redeeming feature to any one of the characters. All this makes the characters appear remote from the real life. The specific emphasis on evil also reflects the cynical attitude of the playwright towards humanity.

Alvin Kernan (1978) is of the opinion that Jonson creates comedy by caricaturing i.e. by likening the human beings to the base metal and Nature to the process of alchemy. There is also a suggestion that just like the base metals are hoped to be turned to finer metals by passing through the alchemical process, the base human beings presented in the beginning of the play would also be transformed into finer beings. For Nature also works on the same principle: "Nature does, first, beget th' imperfect: then $\backslash$ proceeds she to the perfect." (II.i.368-369). But the hope is not fulfilled and one is disappointed to see at the end that just as the base metals are unchanged, the human being also remain the same.

According to F. H. Mares, the theory of alchemy is used by Jonson to enhance the comic effect of the play. But the effect created by the use of this theory is something different. It is that of disgust and disappointment. A careful reading of the play reveals that the basic substances that constitute the matter of The Alchemist are the same that Jonson's alchemist (Subtle) uses: "Menstrues and materials," (II.i.403-408).

Out of these hideous and repulsive materials Jonson creates a world. The worth of the characters presented in the play cannot be any more than this. There is also a strange likeness in the creations of both Subtle (the alchemist) and Jonson. The human beings (characters) created by Jonson in this play seem to have arisen out of dirt: "The vermin, have I tak'n thee out of dung," (I.i.64). Same are the creations created by the art of the alchemist: "Subtle: Art can beget bees, hornets, beetles, wasps, \Out of the carcasses and dung of creatures;" (II.i.382-383). Kernan refers to the world of Jonson as, "...A world of unregenerate, roiling biological substance and mere chemical process." (Kernan 165).

So, these are the raw materials out of which mankind has evolved to satisfy his animal desires of possessing and snatching things away from his fellow beings. And the basic scene of Jonson's play is to capture this rising of man from this raw material into the animal kingdom who in the guise of human beings is working in the society. That is why Edmund Wilson remarks about the play that "the cynicism is carried right through." (Wilson 63). In this play Jonson has enlisted what is negative and recessive in human beings. The play is a vision of all the human beings "soar[ing] out of their humanity" (Kernan 172). There is a possibility of change but it is as limited as the chances of success in alchemy. The transformation that takes place is in the case of human beings is analogous to that of the metals. For instance, Jonson has showed the characters arising out of this raw material into the animal kingdom not into the human beings (finer metals). In the same way, in the hope of getting elixir, which will have miraculous curing powers, the alchemist in this play gets "something about the shards \will cure the itch: though not your itch of 
mind, sir." (IV.iii.100-101). The true alchemical (transformational) miracle in both the cases can be accomplished by a man who is free from sin. Such men, in Jonson's opinion do not exist. So, in Jonson's play, man in himself and by his own virtue lacks the stone and thus leads to the breakdown of the society. The human beings are thus reduced to "the vessels $\backslash$ Of pride, lust, and the cart." (V.iii.25-26). The world in Jonson's The Alchemist is a near return to primitive chaos and it is made clear that the distortion and infection in men would never let human beings achieve the status of a civilization.

Alexander Leggatt regards the play as a finally constructed and delicately balanced comedy. But the play does not come up to all the standards of a comedy. It lacks something. For instance, according to Frye's opinion on the comedy of Ben Jonson: "Comedy moves inevitably towards the elimination of the unhealthy, the disabling, the sterile elements in society, and this movement culminates in the creation of new and healthier society serving the realistic needs of its people." (Kernan 176). But in The Alchemist, at the end, there is no sense of a better and more stable society having evolved out of the whole process. The play contains a ruthless despair and a sense of utter frustration. There is no virtue immanent in any man. There is none of the usual restorative forces in society. There is an absence of any optimistic reaction of a noble man (Lovewit) who would set the things right. Nor is there an evidence of any effectiveness of society or its laws. So, the play cannot be called a comedy in an absolute and exclusive sense of word. As Alvin says that the play "...does not quite fit the comic formula of an irresistible and joyous triumph of vitality and reality over death and illusion in which the perverted elements of society are salvaged and included in the brave new world." (Kernan 177)

The Alchemist does not end on a note of happy achievement. On the other hand, the characters are left with worthless trash: "A peck of coals, or so, which is cold comfort, sir." (IV.iii.81) and "All flown, or stinks, sir." (IV.iii.97). This is the world as Jonson envisages it. This view of the world exists not only in his plays but in his poem also. In his poem "To the World" he calls the world as "False World" (Jonson 95) and then goes on to say: "Yet art thou falser than thy wares. (Jonson 95). One cannot find a representation of anything substantial or true in the play as well. It is an utterly bleak world where there is no hope left.

Greed and Lust are the most prominent features that are present in almost all the characters of the play. Nobody is sincere to anyone. They are like animals that would devour its fellows. The three partners, the only ones in the play who are presented as having a bond between them are insincere to each other. Their relationship is shown as having the seed to destroy themselves. The play opens with a quarrel between Face and Subtle. The war between them is announced with a loud bugle call by Subtle who threatens Face, "I fart at thee." (I.i.2). With this bang, right in the beginning of the play, a stink blasts and prevails throughout the play. Doll says, "Will you undo yourselves with civil wars?... \Nay general, I thought you were civil_" (I.i.82.87).

Deception and quarrels are found not only among these three but also with others. This idea of "civil war" (I.i.82) can be seen throughout the play till the end where Lovewit, apparently a positive character, fights with others for what is not his: "I shall confute you with a cudgel" (V.iii.107) and "Come, will you quarrel? I will feize you, sirrah. \Why do you not buckle to your tools?" (v.iii.132-133). In the world presented by Jonson, there is not a single human being who would care for his fellow beings. 
This is what actually happens in Volpone, another grim comedy by Ben Jonson. In this play, Cornivo, the husband, sends his wife to a rich man whose riches he wants to win. Mammon in The Alchemist goes on to draw on wide range of personages who can be won by gold. Jonson has drawn on a world where money can buy anything, even the conscience of man. There is not a single character in The Alchemist who cannot be bought with money. Lovewit, who may be viewed as a positive character, ignores all the evil around him for the profit he wins is big enough for him to resist.

To F. H. Mares, Mammon's vision appears to be dream-like and attractive. He even goes on to say that Mammon's fantasy is expressed in beautiful poetry that appeals to the aesthetic sense. But if read carefully, this fantasy of Mammon starts looking infected and diseased. His ideas of luxury are distasteful. His speeches move from vulgarity to utter repulsiveness:

I myself will have

The beards of Barbels serv'd, instead of salads;

Oiled mushrooms; and the swelling unctuous paps

Of a fat pregnant sow, newly cut off, " (II.i.185-188)

The mirrors that he wants to be cut and reflect dispersed images of his naked body create images of fragmentation. Such images of dismemberment suggest the potential fragmentation and dissolution of personal identity. It brings forth the depravity or perversion in which he is living in reality. His lust is all the more perverted. He says, "I'll ha' no bawds, $\backslash$ But fathers and mothers. They will do it best, \Best of all others," (II.i.162-164). So, the emphasis is more on the depravity than on his stupidity here.

Ian Donaldson sees the comic effect of the play in the mad pursuit of wealth by all the characters in the play. But then more appropriately, it is a sad depiction of how the love of wealth and the fear of poverty lead a host of men and women upon the most desperate adventures. Henry Wells remarks: "a certain tragic seriousness is evoked by the spectacle of miserable mortals staking their all upon a dream." (Wells 201). Face, Subtle and Doll are playing with the most sacred things of life i.e. men's hearts, souls and honour. At the end, what is left of these beings is recognized by Face as, "We are but faeces, ashes." (IV.iii.48). Finally, "All [is] flown or stinks," (IV. Iii. 96)

Discussing the play as a satirical comedy, Richard Harp deals with the Anabaptist episode as the funniest example in the play. But again, Jonson has brought to attention only the negative aspects of his sphere. The Anabaptists are shown to be the most hypocrites of men. Jonson uses the jargon of religious men to expose their greed. They come to Subtle and Face when they know that both of them are evil. But they come there knowingly and that to accumulate wealth.

All the characters in The Alchemist are befooled in one way or the other. This, according to Robert C. Evens, creates much comedy in the play. It may seem comic to some extent but on the whole, it is sad and gloomy. For all the characters, when they are so confident of their wits, actually prove themselves to be fools. They appear to be mad-folk. 
Lovewit himself realizes that "The world's turn'd Bethlem." (V.i.147). The worst of all is that no truth can survive in this kingdom of fools. It looks like a chorus of fools blindfolded and singing the songs of the miracles of the philosopher's stone. Surly tries to raise his voice against it but is defeated. In this regard, Surly's name is important as well as apt. His name means gloomy and miserable and in the play it is he who insists on the sad truth of the circumstances. He says, "Alchemy is a pretty kind of game, \Somewhat like tricks O' the cards, to cheat a man \with charming." (II.i.390-391). But it is a world where his truth is of no use. He fails because everybody is there to help the frauds for their own interests and also because he himself is trying to make the best of all what he declares to be deception. The characters do not have the potential to conceive the truth or to help it. Even Dame Pliant to whom Surly tells everything is not able to realize or assist the truth and is taken in once again. The intellect of all the characters is blown away because of their overpowering lust for money, "... no sower, \But floods of gold, whole cataracts, a deluge," (IV.i.256). This picture of men, the finest creature of God, becomes all the more gloomy and miserable because this foolery is based on greed and lust. Mammon expresses his love for Doll as thus: "She shall feel gold, taste gold, hear gold, sleep gold: \ Nay we will concumbere gold." (IV.i.29-30). Even Lovewit joins in and is taken by this torrent of greed.

J. B. Bamborough calls Jonson a determined realist. But then, Jonson's characters are portrayed in such a way that they cease to be human. They are not the sort of people one lives with or one wishes to live among. The reader or audience is dismayed by the absence of any goodness of heart in Jonson's characters. The aspiration that can be traced in the case of almost all the characters also is a negative aspiration. It negates not only truth and virtue but also the human relationship. Mammon who wants to appoint Lungs (Face) as the incharge of his harem, tells Face, "But do you hear? \I'll geld you Lungs." (II.i.136137). Furthermore it is not only the cheats who are deceiving the others but all the other characters are also doing the same thing. For instance, Drugger deceives not only Kastril and Dame Pliant but also Surly. He does this all in hope of gaining something. Lovewit deceives almost everyone at the end of the play only because it would help him to marry a widow. So, there is no sense of fellowship left in the human beings in the play.

The world portrayed in Jonson's plays is a wasteland because there is no hope of a humanity better than the one presented and that too is in a distorted and grotesque form. The critics also "had looked on Jonsonian terrain and seen only a wasteland." (Barish 9). Jonson has carefully excluded anything that might bring into play any sympathies or anything positive. All this leads to a sense of wariness, depression and disillusionment. One's faith in human beings becomes corroded.

Bernard Shaw characterized Ben Jonson as a "brutal pedant" (Shaw 61). In his opinion Jonson is insensitive and aggressive. And this is the kind of persons that he portrays in his plays. Furthermore, there is no love in Ben Jonson's plays to set against the host of negative values. The references to seduction or even marriage suggest nothing but the coldest of appetites, either of lust or of money. This may be true both for Mammon and for Surly.

Aggression may also be seen in the way women are treated by these selfish and greedy men. Dame Pliant is forced violently by her brother Kastril to have a sexual relationship with a Spanish Lord (Surly) because it may help him raise his status. He says, "God's lid, you shall love him, or I'll kick you." (IV.ii.6). He calls her "Gull" and "Noddy" 
(IV.ii.72) when he himself is so. He says, "Ass my suster, \Go kuss him, as the cunning man would ha' you, \I'll thrust a pin i' your buttocks else." (IV.ii.74-76). And when she does so he calls her as "Punk, cockatrice," "whore" and a "puss" (V.i.127.131). He maltreats her even when she marries Lovewit: “Did not I say, I would never ha' you tupped / But by a dubb'd boy, to make you a Lady-Tom? (V.iii.126-129).

David Bevington admires Ben Jonson for the exuberance of his style, especially in comedy. But it seems that Jonson is able to extract from all the cheap and dirty aspects of London. In Wilson's opinion, Jonson "can only squander excrement." (Wilson 71). He cannot separate his characters from the smelly and dirty earth. The elements that they live in are the very elements of satanic practices. Tribulation establishes a connection among Satan, fire and fumes. He says, "What makes the devil so devilish,... \Satan, our common enemy, but his being $\backslash$ Perpetually about the fire, and boiling $\backslash$ Brimstone and arsenic? (III.i.24-26). There is an animality and malice involved in the portrayal of human beings. As the action develops and the number of the characters increases, there is an increasing tension. And at the end there is a final blast with which the stink spreads everywhere. Ananias says, "...you seed of sulphur, sons of fire, \your stench, it is broke forth: abomination \Is in the house." (V.i.136-138)

As the play proceeds, the passion for money becomes harder, hungrier and less forgivable. All this brings forward a feeling shared by different classes and conditions of men. The play and especially Lovewit's house starts looking like a micro view of the macro world as perceived by Jonson. That is why, when in the final scene, all the characters are abusing each other, it seems as if they are defining the humanity in general:

Ananias: Locusts

Of the foul pit.

Tribulation: Profane as the bell and the dragon.

Ananias: Worse than the grasshoppers or the lice of Egypt...।

Scorpions

And caterpillars...।

They are the vessels

Of pride, lust and the cart." (V.iii.10-12,20,23)

Since the play presents the society wholly, it is a presentation of humanity. There is a representation of law, trade, religion, landed gentry, prostitution etc., including almost all human professions. These different kinds of people and professions are presented as the "hydra of villainy" (Iv.iv.88) i.e. different faces springing from the same base of villainy. That is why when Ananias prays against the house, it seems it is a prayer against the world. For the world has got a representation here in Lovewit's house. Ananias says, "... may dogs defile thy walls $\backslash$ and wasps and hornets breed beneath thy roofs $\backslash$ this seat of falsehood and this cave of cozenage." (V.iii.113-115) 
In Morris' opinion, the vitality of the wit lifts the play from the despairing mood. But this is not so because the wit is used to a negative end and even there, it is finally unable to give anything to the cheats even. It helps so that truth should not succeed in overcoming falsehood. Surly, having failed to expose deceit and gullibility comes to speak badly of honesty. The master is more concerned with getting what he can out of the situation. In this dog-eat-dog society, the only survivor is the one who is ruthless, unscrupulous and exploitative. Truth and honesty are regarded as disqualifications for success. All this makes the play comically ineffective. There is a mudslinging of all the faces, which is more miserable than farcical.

Paul Goodman refers to the end of the play as a return to normalcy. But then, if it is normalcy, Jonson explains it as a condition in which there is a continuation of evil practices in which truth or beauty cannot thrive. Lovewit, here, advises the audience to deviate from the strict standards of honourable conduct if it is profitable: "Stretch age's truth sometimes, and crack it too." (V.iii.156). The nourishment is promised only to vice, dishonesty and ugliness. This conception of normalcy is again despairing and quite different from the one that is usually found in comedy.

Despair in this play impinges upon the comic spirit. There is no potential of goodness or resourcefulness. Wit, which seems to be resourceful is used to such an end that it sets a limit upon its being pleasing. It rather embitters the taste of the audience who is made to see the distorted picture of humanity, distorted to the extent that it becomes unbearable. It may be seen as equivalent to the cheese which in Face's opinion "breeds melancholy: \And that same melancholy breeds worms;" (III.ii.54-55). It is proved in this play that Jonson cannot write a comedy "without causing ugly ripples." (Blake 133). The laughter produced in this case is a sinister laughter. It is not a hearty laughter which is enjoyable. The playwright seems to be laughing at humanity and its hope of improvement. He proves this case hopeless and says, "What a great loss in hope have you sustain'd!" (V.iii.76).

In my opinion, in writing The Alchemist Jonson fails as a comedy writer. Instead of producing a highly entertaining comedy, he gives us a sad version of a grotesque humanity, a humanity whose prime concern is to enjoy "Perpetuity \Of life and lust." (IV.i.165-166). Such a view of humanity can lead the reader or the audience to only one conclusion which is the same as that of Mammon:

"I will go mount a turnip-cart, and reach,

The end 0' the world, within these two months_" (V.iii.81-82) 


\section{References}

Barish, J. (1980). "Introduction". The Twentieth Century Views Series; ed. Jonas A. Barish. New Delhi: Prentice Hall of India Pvt. Ltd.

Blake, A. (1983). "Sportful Malice”. Jonson and Shakespeare; ed. Ian Donaldson. London: The Macmillan Press Ltd.

Blisset, W. (1987). “The Venter Tripartite in The Alchemist”. Modern Critical Interpretations; ed. Harold Bloom. New York: Chelsea House Publishers.

Jonson, Ben (1967). The Alchemist ed.J. B. Bamborough. London: The Macmillan Education Ltd.

Jonson B. (1975). "To the World". Ben Jonson: Poems; ed. Ian Donaldson. London: Oxford University Press.

Kernan, A. (1978). "Base Metal into Gold". The Selection of Critical Essays; ed. R.V. Holdsworth. London: The Macmillan Press Ltd.

Partridge, E. (1964). “The Alchemist”. The Broken Compass. London: Chatto and Windus Ltd.

Venables, M. (1970). "The Alchemist". Volpone and The Alchemist. Salisbury: The Salisbury Press Ltd.

Wilson, E. (1980). "Morose Ben Jonson". The twentieth Century Views Series; ed. Jonas A. Barish. New Delhi: Prentice Hall of India Pvt. Ltd.

Wells, H. (1939). "Satirical Comedy". Elizabethan and Jacobean Playwrights. New York: Columbia University Press. 